\title{
FARMING IN SOUTHLAND
}

\author{
A. R. RANKIN
}

Fields Superintendent, M inistry of A griculture and $F$ isheries, Invercargill

\author{
J. G. BRUCE \\ Scientist, DSIR, Gore
}

\section{INTRODUCTION}

To REACH Lake Te Anau 25 years ago, one travelled through miles of bracken fern - grey in colour and harsh in appearance. The surrounding hills seemed inhospitable - and towering above them the erosion-scarred mountains seemed both forbidding in appearance and majestic in size. One experienced a feeling of remoteness, of insignificance, and above all a realization that, when compared with the forces of nature, man was a rather puny creature.

Nevertheless, man attempted some changes. Bracken gave way to ryegrass, dusty gravel roads to tar-sealed highways, aeroplanes dropped seed and fertilizers, sheep numbers increased rapidly, Hereford and Angus cattle dotted the landscape, and even the city dwellers of Invercargill gazed in wonder at acre upon acre of autumn clover in full flower carpeting the ground like snow.

Land development was suddenly big business. Change was in the air - not only in the Te Anau basin, but on the hills of northern Southland, on the river valleys and on the vast plains stretching to the coast.

It is hoped to pin-point these changes - the changes that have taken place since the last Grassland Conference in Southland in 1960.

At that Conference, G. Watt, then Commissioner of Crown Lands, Invercargill, tabulated the stock in Southland at that time and made predictions for 1970 and 1980. There were in 1960 5,754,000 sheep in Southland - as many lambs are now killed in one season. The estimate for 1970 was $7,176,000$ but a figure of $7,975,000$ was obtained. It is anticipated that the estimate for 1980 of $8,452,000$ will also be exceeded by about 800,000 . Cattle numbers, however, are more sensational. A mere 109,000 in 1960 had grown to 251,000 in $1970,116,000$ ahead of estimate and 80,000 ahead of the estimate for 1980 of 171,000. This has now been revised to 450,000 . 
The land on which these stock are carried varies tremendously in topography and fertility. From the mountains of Fiordland in the west run the ever-widening valleys of the four main rivers, the Waiau, Aparima, Oreti and Mataura, all of which flow approximately south to Foveaux Strait. These river valleys are of particular interest because they broaden out to form the extensive plains, on the coastal portions of which are located many of Southland's high producing farms.

The most extensive of these is the Southland plain lying immediately behind Invercargill and to the south and west of the Hokonui Hills which divide Eastern and Western Southland. The area of the Southland plain is about 282,800 ha.

Other extensive plains are the Waimea, Waiksia, Five Rivers and West Plains, totalling in all about a further 282,800 ha. The Edendale plain, about 80,000 ha, is naturally drained and is regarded as some of Southland's most fertile land.

Broadly the coastal area of Southland has the highest rainfall and the highest fertility. As one travels inland, the coastal rainfall of 1,016 to $1,143 \mathrm{~mm} /$ annum drops to around $760 \mathrm{~mm}$ at Lumsden, $80 \mathrm{~km}$ inland.

\section{SOILS}

Cutler (1960) has described the soils of Southland in the following manner: The basic soil pattern of Southland is fairly simple. There are three groups of soils delineated primarily by climatic factors. First, there are those with a seasonally dry climate. These consist of yellowgrey to yellow-brown earths intergrade and they occur on the inland parts of Southland where the rainfall ranges from 762 to $1,016 \mathrm{~mm} /$ annum and where the upper soil horizons dry out in summer. Droughts may occur in some years and pan formation (weakly to strongly mottled) is common. The topsoils are generally dark grey silt loams with weak to moderate nut structure. Secondly, there are the soils with damp climate, the yellow-brown soils. These soils are widespread in the humid parts where the rainfall is 1,016 to $1,524 \mathrm{~mm} / \mathrm{annum}$. The profiles are friable, usually free-draining subsoils, with weak to moderately nut and crumb structured topsoils.

The damp climate soils can be divided intd two sub-groups: the lowland and highland soils. The lowland soils, below about $750 \mathrm{~m}$ altitude, are mostly silt loams, but some inland stony soils occur, for example, the moraines in the Te Anau district. 
Soils in the Te Anau district occur in humid conditions where annual rainfall ranges from $900 \mathrm{~mm}$ to about $1,300 \mathrm{~mm}$, though immediately to the west the precipitation is higher. The region is undulating to moderately steep with altitude ranging from $200 \mathrm{~m}$ to about $750 \mathrm{~m}$ while flanking mountains are in excess of $1,500 \mathrm{~m}$. The physiographic features are largely glacial in origin and much of the parent material deposited by glacial action. Original vegetation included fern, scrub, and beech forest, with fescue and red tussock on the higher land to the east.

The highland soils are those above about $7.50 \mathrm{~m}$ to $1,800 \mathrm{~m}$. They are mostly shallow soils, weakly developed and friable. In their natural state they carried snow grass but much of this has been destroyed over the last 100 years. Large areas are now severely eroded.

The third and final group of soils are the wet climate soils, the podzolized yellow-brown earths formed under rimu, rata, kamahi and beech forest on the lowlands and under alpine vegetation and tussock on the highlands. They are of low fertility with poor drainage and are generally unsuitable for agriculture.

Though these three groups comprise the majority of Southland soils, there are also smaller areas of alluvial river flats, suitable for cropping - organic soils, such as Seaward Moss and some coastal sand soils.

To generalize, Southland soils can be described as being low to very low in natural fertility and are either liable to erosion or need drainage.

\section{LIME}

In 1960, there were twelve limeworks in Southland producing 300,000 tonnes a year. Today there are eight limeworks with a total production only about two-thirds that of 1960 .

The value of lime is well appreciated in Southland and at one time the application of seven to eight tonnes of lime/ha prior to sowing pasture was not uncommon. Also not uncommon was the topdressing of pasture with 2.5 tonnes of lime/ha each year. These quantities marked the upper limit but they illustrate the Southland penchant for liming at that time. In 1960 many $\mathrm{pH}$ levels were around the 7.0 mark.

Today, liming, while still regarded as important, is much more restrained. Two and a half to 5 tonnes/ha prior to sowing and a further 2.5 tonnes/ha once every six years would be fairly close to common practice. 
In 1960 it was mentioned that excessive liming was suspected as one culprit in the all-to\&prevalent problem of lamb ill-thrift. This seemed to be a problem on the properties of good farmers, those who topdressed well and limed heavily. Lime was implicated solely by association, but gradually on each successive farm where liming stopped a slow but marked improvement in lamb thrift became apparent. There were many at that time who were convinced that the problem was simply a reflection of moving from 7.5 to 12.5 sheep/ha. But today, with carrying capacities ranging from 15 to 20 ewe equivalents/ha on the higher producing farms, the problem of ill-thrift is non-existent.

\section{FERTILIZERS}

While lime usage has decreased, dependence on superphosphate has markedly increased. Well over 200,000 tonnes of phosphatic fertilizers are applied each year and this figure is showing a steady rise. Up to 1.5 tonnes/ha of $0-9-\mathrm{O}$ superphosphate may well be required during land development but, once obtained, satisfactory levels can be usually maintained with $251 \mathrm{~kg}$ of $0-9-\mathrm{O}$ superphosphate/ha/annum. Though superphosphate is universally required, potash deficiency is not so widespread. The first potash responses were obtained on the Edendale silt loam and the use of potash on this soil type is now widespread. The Waikiwi silt loam also responds to potash, while other yellow-brown earths are more inconsistent in their response to potash applications.

Owing to the universal use of superphosphate, sulphur is not a limiting factor except perhaps on yellow-grey earths in the drier area of northern Southland.

Nitrogen has played an increasingly important role over recent years. It is principally used to increase the yield of grass seed and wheat crops, to stimulate out-of-season production, and to improve the yield of hay crops,

\section{TRACE ELEMENTS}

Cobalt is extensively used over a large area of Southland. Morton Mains was the initial deficient area hence the term "Morton Mains" disease. Cobalt is usually applied as cobaltized superphosphate or in some cases applied as a spray. Boron deficiency, aided by high $\mathrm{pH}$ levels, is widespread but manifests itself mainly as "brownheart in swedes" and occasionally as "lucerne yellows". Iodine deficiency, particularly in the middle of the Southland plain, gives risc to goitre in lambs, while copper deficiency is 
common on the wetter coastal strip where soils are peaty in nature. Selenium is used both to assist lamb fattening and to improve lambing percentage. However, the use of selenium is not by any means universal.

\section{PASTURES}

Twenty-five years ago in Southland it was necessary to grow about 8 ha of swedes each year for winter feed for each 1,000 ewes. By 1960 improved fertility from topdressing, grcater use of 'Grasslands Manawa' short-rotation ryegrass, and the introduction of the technique of autumn-saved pasture had reduced the dependence on swedes to about 5 ha/1,000 ewes. And this leads to the next and probably main change to be pin-pointed. Since 1960, topdressing has increased, stocking rates have risen quite dramatically, and fertility improvement has been marked.

Improved grass species and perhaps most of all better utilization and changed grazing techniques have, on the more fertile areas of Southland, removed swedes entirely from the diet of sheep. In these areas, winter grass dormancy is, if not entirely eliminated, at least significantly reduced. The techniques of what is termed all-grass farming are to be' discussed fully in subsequent papers.

The pastures that predominate are usually fairly mixed, although some straight ryegrass/white clover pastures are sown, Ryegrass, either Ariki, Ruanui, Manawa or a combination of these, at about $20 \mathrm{~kg} / \mathrm{ha}$, cocksfoot at $3 \mathrm{~kg} / \mathrm{ha}$, timothy at $3 \mathrm{~kg} /$ ha, Huia white clover at $3 \mathrm{~kg} / \mathrm{ha}$, and perhaps crested dogstail at 0.5 to $1 \mathrm{~kg} / \mathrm{ha}$, is perhaps generalizing but it'represents the type of pasture normally sown.

On the higher fertility country, pasture production is round $12,000 \mathrm{~kg} \mathrm{DM} /$ ha with about $5,590 \mathrm{~kg} \mathrm{DM}$ in the summer, 3,440 in autumn, 650 in winter and 4,280 in spring.

The wide seasonal variation illustrates the point around which Southland agriculture revolves, inability to carry in the winter period the stock which summer growth makes possible. This leads to one major weakness, grass utilization during the summer period when pastures are often rank and poorly grazed. The problem is compounded by rather inconsiderate weather during the hay-making period.

However, despite these problems, impreved soil fertility, sound management and good stockmanship make, the carrying of 20 ewe equivalents/ha not uncommon on quite a proportion of the plains country. 
On tussock country and the bracken land around Te Anau the last 10 years have also brought changes. During this time the technique of topdressing and oversowing became established. Blocks were broken into manageable areas using lighter fencing materials, stock concentrated to trample out undesirable species, and inoculated and pelleted clovers and grasses were sown by air. Sulphur-superphosphate at $188 \mathrm{~kg} / \mathrm{ha}$ on silver tussock country and molybdic-superphosphate at round $377 \mathrm{~kg} / \mathrm{ha}$ on red tussock country are the usual initial applications followed by $188 \mathrm{~kg}$ superphosphate in subsequent years,

\section{CROPPING}

A variety of crops is grown in Southland, the major one being wheat. In this last season the wheat acreage totalled about 21,000 ha and usually fluctuates between 12,000 and 21,000 ha depending on the likely return for meat and wool. Wheat yields on the better country are between 2 and 3.25 tonnes/ha. Oats and barley are also grown as spring-sown crops, while cocksfoot, timothy, browntop, fescue and dogstail are the main small seeds.

The last 10 years have seen the installation of large numbers of drying and bulk-handling plants for seed production.

\section{FARMING SYSTEM}

An attempt to translate this informatioa to a farm basis will now be made.

A typical farm on the plains of Southland would be about 120 ha, carrying 1,600 breeding ewes, 400 hoggets, 40 fattening cattle, and growing 4 ha wheat. This farmer has changed to grass wintering and provides round 2,000 bales of hay for the sheep and 1,000 bales for the cattle. He still runs a straight Romney flock mating to the Southdown ram but is watching with interest one or two farmers who run Coopworth-Romney Border cross and even Perendale ewes. As fat lamb sires, Dorset Down and Suffolk are enjoying a rapidly increasing popularity. The ewes have a lambing percentage of 115 to 120 .

Meat production is in the vicinity of $240 \mathrm{~kg} / \mathrm{ha}$ and wool production reaches $90 \mathrm{~kg} / \mathrm{ha}$. Two and a half tonnes of lime/ha is applied every seven or eight years to the rather mixed sward which, in addition to the sown species of ryegrass, cocksfoot, timothy and dogstail, also has a sprinkling of poa annua, Yorkshire fog and flatweeds. As well as lime, $251 \mathrm{~kg}$ cobaltized superphosphate/ha are applied each year with potash as a possible 
additioa if it is on Edendale or Waikiwi soils. Drainage is important so the farm has been extensively tiled and moled. Grass' grub and porina annoy occasionally but Californian thistle (Cirsium arvense) is almost an occupational hazard. The farmer is worried about the spread of nodding thistle (Carduus nutans) and while he marvels at the way the back country is responding to oversowing and topdressing he realizes that some of this country is changing from store to fattening country. This, coupled with the upsurge in stocking rate on the northern Southland runs, severely limits the supply of store lambs, sheep, and cattle for fattening.

He growls about the Southland climate but when pressed admits the absence of extremes and confesses that Southland is not a bad place to farm.

\section{REFERENCE}

Cutler, E. J. B., 1960. The soils of Southland and their potential uses. Proc. N.Z. Grassld Ass., 22: 15-26. 